\title{
WPS2823
}

Policy Research Working Paper 2823

\section{Real Exchange Rate Uncertainty and Private Investment in Developing Countries}

\author{
Luis Servén
}

The World Bank

Latin America and the Caribbean Region Office of the Chief Economiest April 2002 


\section{Abstract}

Servén examines empirically the link between real exchange rate uncertainty and private investment in developing countries using a large cross country-time series data set. He builds a GARCH-based measure of real exchange rate volatility and finds that it has a strong negative impact on investment, after controlling for other standard investment determinants and taking into account their potential endogeneity. The impact of uncertainty is not uniform, however. There is some evidence of threshold effects, so that uncertainty only matters when it exceeds some critical level. In addition, the negative impact of real exchange rate uncertainty on investment is significantly larger in economies that are highly open and in those with less developed financial systems.

This paper-a product of the Office of the Chief Economist, Latin America and the Caribbean Region-is part of a larger effort in the region to assess the effects of macroeconomic volatility. Copies of the paper are available free from the World Bank, 1818 H Street NW, Washington, DC 20433. Please contact Patricia Soto, room I8-018, telephone 202-473-7892, fax 202-522-7528, email address psoto@worldbank.org. Policy Research Working Papers are also posted on the Web at http://econ.worldbank.org. The author may be contacted at lserven@worldbank.org. April 2002. (18 pages)

The Policy Research Working Paper Series disseminates the findings of work in progress to encourage the exchange of ideas about development issues. An objective of the series is to get the findings out quickly, even if the presentations are less than fully polished. The papers carry the names of the authors and should be cited accordingly. The findings, interpretations, and conclusions expressed in this paper are entirely those of the authors. They do not necessarily represent the view of the World Bank, its Executive Directors, or the countries they represent. 


\title{
Real exchange rate uncertainty and private investment in developing countries
}

\author{
Luis Servén*
}

The World Bank

April 2002

JEL classification codes: E22, C23

* I thank Michael Gavin, Norman Loayza, Fabio Schiantarelli, two anonymous referees and the co-editor for helpful comments and suggestions on an earlier draft. Charles Chang provided excellent research assistance. 



\section{Introduction}

Developing economies suffer from a high degree of macroeconomic uncertainty. Growth, inflation, real exchange rates and other key macroeconomic variables are much more volatile than in industrial economies, and the consequences of this excess volatility for aggregate performance in several dimensions -- growth, investment and trade -- have attracted some attention in recent empirical literature. ${ }^{1}$ In the case of investment, this concern has been renewed by recent theoretical work identifying several channels through which uncertainty can impact on investment, under various assumptions about risk aversion, adjustment costs to investment and other factors (see Caballero 1991 and Abel and Eberly 1994). However, some of these effects of uncertainty operate in mutually opposing directions, and their magnitude depends on a variety of factors identified in the literature. As a result, the sign of the investment-uncertainty relationship is indeterminate on theoretical grounds.

This paper examines empirically the link between real exchange rate uncertainty and private investment in LDCs. The high real exchange rate volatility that characterizes developing economies creates an uncertain environment for investment decisions by making absolute and relative sectoral profitability (i.e., in the traded vs. nontraded goods sectors) and the cost of new capital goods (because of their high import content) all harder to predict. ${ }^{2}$ Using a large cross country-time series dataset, the paper examines the

\footnotetext{
${ }^{1}$ The excess volatility of LDCs is amply documented by Easterly, Islam and Stiglitz (2000), who also examine the consequences for growth. The literature exploring the impact on trade is summarized by Arize, Osang and Slottje (2000), while that on investment is reviewed by Servén (1998).

2 The volatility of real exchange rates in LDCs is documented for example, by Interamerican Development Bank (1995). Servên (1998) finds in a principal components framework that the real exchange rate plays a leading role to summarize the combined volatility of five key macro variables -- GDP growth, inflation, the terms of trade, the relative price of capital goods and the real exchange rate itself.
} 
impact of real exchange rate uncertainty on private investment controlling for standard investment determinants, and assesses the role of key features of the economy - such as the degree of openness and financial development, the income level and technological factors -- that may tend to augment or mitigate such impact.

The paper is organized as follows. Section 2 summarizes briefly the relevant analytical literature as well as the empirical studies on real exchange rate uncertainty and investment. Section 3 lays out the paper's econometric methodology, and section 4 presents the empirical results. Section 5 concludes.

\section{Real exchange rate uncertainty and investment: a brief overview}

Many developing economies experience high real exchange rate volatility. This translates into a high degree of uncertainty for private investors regarding both the profitability and the cost of investment. Volatile real exchange rates are associated with erratic swings in the relative profitability of investment in the traded and nontraded goods sectors of the economy. In turn, the cost of new capital goods also becomes uncertain with real exchange rate volatility, due to the high import content of investment in developing countries (Servén 1999).

The impact of uncertainty on private investment decisions has received considerable attention in the literature. Much of the recent analytical work focuses on the case of risk-neutral investors, under which the critical factor shaping the impact of uncertainty on investment is the relationship between the expected marginal revenue product of capital and the uncertain variable - typically prices or output demand. In the familiar scenario of the constant-returns, perfectly competitive firm with capital as the 
only fixed factor, marginal profitability is a convex function of output prices, and Jensen's inequality implies that higher price uncertainty raises the expected profitability of capital, thereby increasing the desired capital stock and hence investment (Hartman 1972, Abel 1983).

Recent literature has shifted the analytical focus to the adjustment costs implied by the acquisition and installation of capital, emphasizing the irreversible nature of most fixed investment projects (Dixit and Pindyck 1994), which makes investment adjustment costs asymmetric - larger for downward than for upward adjustment. Under appropriate conditions, this creates a range of inaction: investment takes place only when the difference between expected profitability and the cost of capital exceeds a certain threshold. The reason is that firms become reluctant to invest due to the risk of getting stuck with too much capital if events turn unfavorable. Even disturbances that raise the profitability of all investment projects, but make their relative ranking more uncertain, can lead to inaction - and hence depress aggregate investment as investors try to avoid the 'irreversible mistake' of investing in the wrong activity (Bernanke 1983).

However, irreversibility per se is not sufficient to turn around the positive impact of uncertainty on investment following from the convexity of the profit function. Indeed, even under asymmetric adjustment costs it can be shown that optimal investment by a competitive firm continues to be a non-decreasing function of uncertainty (Caballero 1991, Abel and Eberly 1994). Reversing this result requires that the marginal revenue product of capital be a decreasing function of the capital stock, as happens under imperfect competition or decreasing returns to scale. Under such conditions, the profitability threshold mentioned above rises with the extent of uncertainty, and if this 
effect is powerful enough it may outweigh the rise in expected profitability stemming from the convexity of the profit function, leading to reduced investment. ${ }^{3}$ Even in this scenario, however, the theoretical predictions of the irreversibility approach concern the ex-ante investment decision, and hence refer mostly to the short-term. In the longer term, a "hangover effect" (Abel and Eberly 1995, 1999) comes into play: higher degrees of irreversibility and/or uncertainty make it more likely that firms will ex-post find themselves stuck with excessive capital, making the long-run capital stock and investment higher than they would have been otherwise.

Of course, if investors are risk-averse rather than risk-neutral, then uncertainty has an independent, adverse effect on investment decisions, which makes it more likely that the overall impact of uncertainty on investment be negative (Zeira 1990). ${ }^{4}$ On the whole, however, the theoretical literature implies that the uncertainty--investment link is ambiguous and may be shaped by a variety of factors. Lee and Shin (2000) emphasize the role of variable inputs - the larger their output share, the stronger the above-mentioned convexity effect and the more likely is investment to rise with uncertainty. Also, the uncertainty-investment link might exhibit 'threshold effects', so that at low uncertainty the relationship could be positive, but turns negative when uncertainty rises beyond some critical level (see Sarkar 2000 for details). Likewise, with risk averse investors the ability to diversify risk is another likely determinant of the impact of uncertainty on investment

\footnotetext{
${ }^{3}$ The assumption that the marginal profitability of capital declines with the capital stock obviously cannot apply to a constant-returns perfectly competitive firm, for which the marginal profitability of capital is, by construction, unrelated to the level of capital. However, such assumption does hold for imperfectly competitive firms and, perhaps more importantly, also for a free-entry perfectly competitive industry taken as a whole (Caballero and Pindyck, 1996).

${ }^{4}$ Disappointment aversion, a concept introduced by Gul (1991) also contributes to make a negative uncertainty-investment link more likely. On this see Aizenmann and Marion (1995).
} 
decisions: better-developed financial markets offering enhanced risk diversification opportunities should reduce the adverse effects of sector-specific volatility - such as that associated with the real exchange rate -- on aggregate investment. Finally, in the case of real exchange rate uncertainty an additional ingredient is the degree of openness of the economy. Other things equal, the impact on real exchange rate volatility on investment is likely to be bigger in economies more exposed to foreign trade. ${ }^{5}$

Against this analytical background, several empirical studies have examined the impact of real exchange rate uncertainty on aggregate investment, ${ }^{6}$ some focusing on industrial economies (e.g., Goldberg 1993 on U.S. industry-level investment; Darby $e t$. al. 1999 on aggregate investment in five OECD economies) and others considering also a few developing economies (Pindyck and Solimano 1993, Servén and Solimano 1993, Bleaney 1996). To date, however, no study offers an assessment of the impact of real exchange rate uncertainty on private investment in a large sample of developing countries, nor have existing studies systematically examined how such impact may itself depend on the factors identified by the theoretical literature just cited. These tasks are taken up below.

\section{Data and methodological issues}

To explore the empirical relation between investment and real exchange rate volatility, I draw from a large cross-country time-series data set on private investment

\footnotetext{
${ }^{5}$ Easterly, Islam and Stiglitz (2000) show that more open economies and economies with less-developed financial systems tend to display higher aggregate volatility. Caballero (2000) develops a model underscoring the role of underdeveloped financial systems in the amplification of volatility in LDCs.

${ }^{6}$ Apart from the real exchange rate, a number of empirical studies examine the impact of other sources of uncertainty on investment; see Servén (1998) and Carruth, Dickerson and Henley (2000).
} 
and its determinants comprising 61 developing countries and spanning the years 1970 to 1995. The panel is unbalanced, with the number of observations per country ranging from a minimum of 5 to a maximum of 24; see Servén (1998) for further details. To measure real exchange rate uncertainty (rather than just sample variability), I use a $\operatorname{GARCH}(1,1)$ specification in a simple equation in which the (log) real exchange rate follows an $\operatorname{AR}(1)$ process with trend, which can have different parameters for each country. ${ }^{7}$ I take the conditional variance from the GARCH procedure as the relevant measure of real exchange rate uncertainty. It displays a strong negative association with the private investment / GDP ratio: the full-sample correlation is -0.30 , with a standard error of .03 .

I next assess the impact of uncertainty on investment controlling for conventional investment determinants. I use an empirical specification with the (log of the) private fixed investment / GDP ratio as dependent variable. In addition to real exchange rate uncertainty, the explanatory variables include the relative price of capital goods, measured by the (log of the) ratio of the investment deflator to the GDP deflator, and the real interest rate ${ }^{8}$; both should exert a negative effect on investment. However, in view of the pervasive role of interest rate controls and non-price rationing mechanisms in developing-country financial markets over the sample period - that may render observed interest rates uninformative as to the true marginal cost of funds $-I$ also add among the regressors a measure of the overall tightness of credit markets, namely the flow of private

${ }^{7}$ This specification is in line with evidence that real exchange rates appear to be trend stationary over comparable panel samples; see Lothian and Taylor (1996) and Frankel and Rose (1996). Using instead an equation in difference form leads to very similar qualitative results, however. See Serven (1998) for a comparison of this GARCH-based uncertainty measure with simpler ones derived from the residuals of recursive $\mathrm{AR}(p)$ equation estimates.

${ }^{8}$ Two alternative measures of the inflation rate were used to construct the real interest rate: (i) the current GDP inflation rate, and (ii) a simple average of the current plus one-period ahead inflation rates. The empirical results were similar in both cases; those reported below use the latter definition. 
credit relative to nominal GDP, which should be expected to exert a positive effect on private investment. ${ }^{9}$ Finally, since I am working with annual information, inertia needs to be taken into consideration, and thus I include the lagged dependent variable among the regressors.

The conventional approach to the estimation of this type of dynamic equation in a panel context is based on the difference GMM estimator proposed by Arellano and Bond (1991), which uses 'internal' instruments to deal with the correlation between the lagged endogenous variable and the time-invariant component of the disturbance. The procedure involves taking differences of the original equation (to remove the time-invariant component of the disturbance) and then using as predetermined instruments lagged values of the levels of the right-hand side variables. In particular, if the time-varying component of the disturbance is serially uncorrelated, the second- and higher-order lags of the regressors (including the endogenous variable) become valid instruments. ${ }^{10}$ This approach has a major drawback, however: if the regressors display persistence over time, their lagged levels may be very poor instruments for their differences. $A$ better alternative is the system GMM estimator of Arellano and Bover (1995) and Blundell and Bond (1998), which combines the equation in differences -- instrumented with lagged levels of the regressors -- with the equation in levels, instrumented with lagged differences of the regressors. The latter become valid instruments under additional stationarity assumptions

\footnotetext{
${ }^{9}$ Alternative specifications used instead the (log of the) real private credit stock or its first difference, with qualitative results similar to those below. Other experiments attempted to capture standard accelerator effects by adding current and lagged GDP to the equation, but they were not significant once the dependent variable is expressed in terms of the log of the investment/GDP ratio.

${ }^{10}$ Provided the time dimension of the data is long enough, this approach can easily accommodate serial correlation of order $k$, under which regressors lagged at least $k+2$ periods are valid instruments.
} 
regarding the time-invariant disturbance. ${ }^{11}$ In the present framework, I use this approach to deal not only with endogeneity of the lagged dependent variable, but also with the potential endogeneity of the other regressors, given that credit, interest rates and so on may be jointly determined with investment. As long as the model is overidentified, validity of the assumptions underlying the system estimator can be tested through Sargan tests of orthogonality between the instruments and the residuals, and through tests of second- or higher-order residual autocorrelation. ${ }^{12}$

\section{Empirical results}

As usual in this kind of cross-country sample outliers are a concern, and to remove them I drop from the sample those observations for which any of the variables lies beyond 10 standard deviations away from the sample mean. This leads to the removal of a dozen data points; use of more stringent criteria leads to dropping additional observations but causes little change in the parameter estimates.

The regressions assume that all the explanatory variables are endogenous, and in consequence they are all instrumented. For the differenced equation in the GMM system, the standard investment determinants are instrumented using the second and third lags of their levels. However, this is not possible with the GARCH-based real exchange rate uncertainty measure because its construction employs future as well as past information, and hence its lagged values may be correlated with the time-varying disturbance. To remedy this, I construct a 'naïve' measure of real exchange rate uncertainty by computing

\footnotetext{
${ }^{11}$ Letting $\alpha_{i}$ denote the time-invariant disturbance and $z$ an explanatory variable, the requirement is that $\mathrm{E}\left[a_{i} \mid z_{\mathrm{it}}\right]=\mathrm{E}\left[a_{i} \mid z_{\text {is }}\right]$ for all $t$ and $s$; see Arellano and Bover (1995) and Blundell and Bond (1998).
} 
the 3-year variance of the forecast errors from an $\operatorname{AR}(1)$ real exchange rate equation estimated recursively - i.e., using current and lagged real exchange rate information only. ${ }^{13} \mathrm{I}$ use the second and third lags of this naive backward-looking uncertainty measure to instrument the first difference of the GARCH-based real exchange rate uncertainty indicator. Finally, as additional instrument I use the current and two lagged values of the terms of trade. In turn, for the levels equation in the GMM system I use as instruments once-lagged differences of the conventional regressors and the terms of trade plus the naïve uncertainty measure.

The first column of Table 1 reports the system GMM estimates of the basic specification. ${ }^{14}$ On the whole, the parameters are very well determined and highly significant. They reveal negative and significant effects on investment of both the relative price of capital goods and the real interest rate. In turn, the credit flow/GDP ratio has a strong positive impact. As for real exchange rate uncertainty, it carries a negative and highly significant coefficient. Finally, the relatively large magnitude of the coefficient on the lagged dependent variable suggests a considerable degree of inertia in the investment / GDP ratio. In turn, the diagnostic statistics are supportive of the chosen specification: the Sargan test shows no evidence against the validity of the instruments, and the serial correlation tests reveal strong first-order autocorrelation of the differenced residuals, as expected, but no traces of higher-order autocorrelation. Thus, on the whole the results in

\footnotetext{
${ }^{12}$ Notice that if the time-varying disturbance in the original equation is serially uncorrelated, differencing will induce first-order (but no higher-order) serial correlation.

${ }^{13}$ The AR(1) equation includes a time trend and is estimated separately for each country; see Servén (1998).

${ }^{14}$ All regressions include a set of year dummies, which were always highly significant.
} 
column 1 are strongly supportive of a negative impact of real exchange rate uncertainty on private investment.

Columns 2 and 3 of Table 1 explore the possibility of nonlinearities and threshold effects regarding the impact of real exchange rate uncertainty, to verify the assertions from the theoretical literature that the effects of uncertainty may depend on its level. Column 2 adds to the basic specification of column 1 a quadratic term in the conditional variance of the real exchange rate. Its parameter estimate turns out positive but highly imprecise, while the other parameters show very little change.

Column 3 takes a different approach to search for threshold effects, which consists in distinguishing between high- and low-uncertainty countries, according to whether their average level of real exchange rate uncertainty is above or below the sample median, respectively, and allowing each group to carry a different coefficient on the uncertainty variable in the regressions. ${ }^{15}$ While the results in column 3 show that this specification causes little change in the parameter estimates of the standard investment regressors, the pattern of the uncertainty coefficients is revealing: the impact of real exchange rate uncertainty is negative and significant only when uncertainty is high. At low uncertainty, the parameter estimate is positive, although very imprecise - so imprecise that it is not possible to reject at conventional significance levels the null hypothesis that the two parameters are equal. With this caveat, these results are consistent with the existence of threshold effects, as argued by Sarkar (2000).

\footnotetext{
${ }^{15}$ It makes little difference if the high and low distinction is made instead in terms of observations, rather than countries, above and below median real exchange rate uncertainty. The resulting parameter estimates are similar but somewhat less precise than those reported in the text. Likewise, using the mean instead of the median yields similar results as well.
} 
Table 2 assesses how the impact of real exchange rate uncertainty on investment is shaped by different ingredients mentioned in the literature. The approach is similar to that just described: in each case, I interact the exchange rate uncertainty measure with dummy variables defining two country groups in the sample, according to the level of the variable of interest - income, technology, financial depth and openness.

Column 1 does this with real per capita income, allowing different impacts of real exchange rate uncertainty in higher-income developing countries (those with 1995 per capita income above the sample median) and the rest. The underlying idea is that uncertainty might have a larger adverse impact in poorer economies, often characterized by less-diversified production structures and weaker institutional and policy frameworks that render them more vulnerable to disturbances. The estimates in column 1 show that the impact of uncertainty is about 50 percent larger in poorer countries. In rich countries the impact is also negative, but smaller and insignificant - although the estimate is imprecise and not significantly different from that for poor countries. The remaining parameters are virtually unchanged relative to those in Table 1.

Column 2 turns to the role of technological factors. As noted earlier, under irreversibility the impact of uncertainty on investment is more likely to be negative the smaller the output share of variable inputs. Unfortunately, aggregate data on factor shares exist for very few countries, and hence I focus instead on the aggregate capital / labor ratio, available from Kraay et. al. (2000). Under the assumption that countries share a common constant-returns CES technology combining labor and capital into value added, the share of labor should be higher (lower) in countries with a higher capital labor ratio if the elasticity of substitution is smaller (greater) than one. As with income, I classify 
countries into two groups according to their 1995 capital/labor ratio. The estimates in column 3 show that the coefficient on real exchange rate uncertainty is negative and roughly similar for both groups, which prevents any clearcut inference on the role of technological factors. Like with income, the uncertainty impact is significantly different from zero only for low capital / labor countries, which is unsurprising given that the capital / labor ratio and per capita income are highly correlated (their sample correlation exceeds .9).

Column 3 focuses on financial depth, measured by the ratio of credit to the private sector to GDP. ${ }^{16}$ As noted above, the presumption is that better-developed financial systems should reduce the impact of real exchange rate volatility on investment, by making it easier for risk-averse investors to diversify the risks associated with their investment projects. As before, I distinguish between countries whose average financial depth is above the median and those below the median. The parameter estimates confirm this presumption: with high financial depth, the negative impact of uncertainty is small and insignificant, while with low depth it is four times larger and highly significant. Further, a Wald test of equality of the two estimates yields a p-value of 6 percent, confirming that they are significantly different from each other. The other parameters show no visible change relative to previous specifications.

Since higher-income countries are typically characterized by a higher degree of financial development, ${ }^{17}$ the results in column 3 suggest that the (weak) differential impact of uncertainty according to income level found in column 1 might actually be due

\footnotetext{
${ }^{16}$ This is the preferred summary indicator of financial depth in the growth literature; see Levine, Loayza and Beck (2000). However, similar results obtain (but sample coverage is smaller) using instead the ratio of liquid liabilities to GDP.
} 
to the different degree of financial development of rich and poor economies. This is explored in column 4 , which adds to the specification in column 1 a differential effect arising from low financial development.. The results continue to show a negative contribution of low financial depth, while the coefficients on the income-based variables are now insignificant both individually and jointly (the Wald test of joint significance yields a p-value of .804$)$. This suggests that once financial depth is taken into consideration income levels do not matter for the impact of real exchange rate uncertainty on investment.

Finally, in column 5 I examine the role of trade openness, which as customary is measured by the sum of imports plus exports over GDP. Other things equal, the impact of real exchange rate volatility should be greater in economies with greater exposure to foreign trade. The parameter estimates in column 5 , however, run counter this presumption. The negative impact of uncertainty is virtually the same regardless of the degree of openness, and significant only for the less-open economies.

This result appears somewhat puzzling and warrants further inspection. As with income, one cause for suspicion is the correlation between openness and financial depth (equal to .41 in the sample). The openness indicator in column 5 may be partly capturing the effects of financial depth. Since the two variables presumably have opposing effects for the impact of real exchange rate uncertainty, the estimates provide an inaccurate assessment of the role of openness.

Proceeding like in the case of income in column 4 - that is, allowing a different uncertainty coefficient for countries with low financial depth, in addition to the separate

\footnotetext{
${ }^{17}$ The sample correlation between financial depth and per capita income is .52 .
} 
coefficients for more and less open economies - yields the estimation results in column 6. Low financial depth continues to be associated with a negative and significant effect of real exchange rate uncertainty on investment. In addition, the coefficients on the high and low-openness country groups now differ in sign: positive (and significant) for low openness and negative but insignificant at high openness. Furthermore, the difference between the two coefficients is highly statistically significant (a Wald test of equality yields a p-value of .01). Thus, once account is taken of the effects of financial depth, higher (lower) openness is indeed associated with a stronger (weaker) deterrent effect of real exchange rate uncertainty on investment, as expected. Specifically, the estimates in column 4 indicate that in economies characterized by underdeveloped financial systems or high openness to trade (or both) the impact of real exchange rate uncertainty on investment is negative, while in less-open economies with well-developed financial systems the impact is significantly positive.

\section{Concluding remarks}

This paper has explored empirically the impact of real exchange rate uncertainty on private investment in a large developing-country panel data set. On theoretical grounds, its sign is ambiguous, and the analytical literature suggests that it may be highly nonlinear and /or depend on economic features such as the output share of variable inputs, the degree of financial market development and trade openness.

The paper finds a negative and highly significant impact of real exchange rate uncertainty on private investment in the overall sample, after controlling for standard investment determinants. However, closer inspection suggests that this impact is larger at 
higher levels of uncertainty - in line with analytical literature underscoring 'threshold effects'. Moreover, the investment effect of real exchange rate uncertainty is shaped by the degree of trade openness and financial development: higher openness and weaker financial systems are associated with a significantly negative uncertainty-investment link. Conversely, under conditions of high financial development and low openness real exchange rate uncertainty may actually have a positive impact on private investment.

\section{REFERENCES}

Abel, Andrew B., "Optimal Investment Under Uncertainty," American Economic Review 73 (March): 228-233 (1983).

and Janice C. Eberly, "A Unified Model of Investment Under Uncertainty," American Economic Review 1369-84 (December, 1994).

“Optimal Investment With Costly Reversibility," NBER Working Paper 5091 (1995).

"The Effects of Irreversibility and Uncertainty on Capital Accumulation," Journal of Monetary Economics 44, 339-377 (1999).

Arize, Augustine, Thomas Osang and Daniel Slottje, "Exchange rate volatility and foreign trade: evidence from thirteen LDCs," Journal of Business and Economic Statistics 18, 10-17 (2000).

Aizenman, Joshua, and Nancy Marion, "Volatility, Investment and Disappointment Aversion," NBER Working Paper 5386 (1995).

Arellano, Manuel, and Stephen Bond, "Some Tests of Specification for Panel Data: Monte Carlo evidence and an application to employment equations," Review of Economic Studies 58, 277-97 (1991).

Arellano, Manuel, and Olympia Bover, "Another Look at the Instrumental Variable Estimation of Error-Components Models," Journal of Econometrics 68, 29-51 (1995).

Bernanke, Ben, "Irreversibility, uncertainty and cyclical investment," Quarterly Journal of Economics (1983).

Bleaney, Michael, "Macroeconomic Stability, Investment and Growth in Developing Countries," Journal of Development Economics 48, $461-77$ (1996).

Blundell, Robert and Stephen Bond, "Initial Conditions and Moment Restrictions in Dynamic Panel Data Models," Journal of Econometric (1998).

Caballero, Ricardo J., "On the Sign of the Investment-Uncertainty Relationship," American Economic Review 81, No. 1, 279-88 (March, 1991). 
"Macroeconomic volatility in Latin America: a view and three case studies," NBER Working Paper 7782 (2000).

and Robert S. Pindyck, "Uncertainty, Investment, and Industry Evolution," International Economic Review 37, No. 3 (August, 1996).

Carruth, Alan, Andy Dickerson and Andrew Henley, "What do we know about investment under uncertainty?," Journal of Economic Surveys 14, 119-153 (2000).

Darby, Julia et. al., "The Impact of Exchange Rate Uncertainty on the Level of Investment," Economic Journal 109, C55-C67 (1999).

Dixit, Avinash, and Robert S. Pindyck, "Investment Under Uncertainty," Princeton University Press. Princeton, New Jersey (1994).

Easterly, William, Roumeen Islam and Joseph Stiglitz, "Explaining Growth Volatility," in Annual World Bank Conference on Development Economics 2000, Oxford University Press (2000).

Frankel, Jeffrey and Andy Rose, "A panel project on purchasing power parity: mean reversion within and between countries," Journal of International Economics 40, 209-224 (1996).

Goldberg, Linda, "Exchange Rates and Investment in United States Industry," Review of Economics and Statistics 75, 575-588 (1993).

Gul, Faruk, "A Theory of Disappointment Aversion," Econometrica 59, 667-686 (1991).

Hartman, Richard, "The Effects of Price and Cost Uncertainty on Investment," Journal of Economic Theory 5: 258-266 (October, 1972).

Interamerican Development Bank, "Overcoming volatility in Latin America," (1995).

Kraay, Aart, Norman Loayza, Luis Servén and Jaume Ventura, "Country portfolios," NBER Working Paper 7795 (2000).

Lee, Jaewoo and Kwanho Shin, "The Role of a Variable Input in the Relationship Between Investment and Uncertainty," American Economic Review 90, 667-680 (2000).

Levine, Ross, Norman Loayza and Thorsten Beck, "Financial intermediation and growth: causality and causes," World Bank Policy Research Working Paper 2059 (2000).

Lothian, James and Mark Taylor, "Real Exchange Rate Behavior: the Recent Float from the Perspective of the Last Two Centuries," Journal of Political Economy 104, 488-509 (1996).

Pindyck, Robert S. and Andrés. Solimano, "Economic Instability and Aggregate Investment," NBER Macroeconomics Annual 8, 259-303 (1993).

Sarkar, Sudipto, "On the Investment-uncertainty Relationship in a Real Options Model," Journal of Economic Dynamics and Control 24, 219-225 (2000).

Servén, Luis, "Macroeconomic uncertainty and private investment in LDCs: an empirical investigation," World Bank Policy Research Working Paper 2035 (1998).

"Terms of trade shocks and optimal investment: another look at the Laursen-Metzler effect," Journal of International Money and Finance (1999).

Servén, Luis and Andrés Solimano, "Striving for growth after adjustment: the role of capital formation," Washington DC: The World Bank (1993).

Zeira, Joseph, "Cost Uncertainty and the Rate of Investment," Journal of Economic Dynamics and Control 14, 53-63 (1990). 
Table 1

Real exchange rate uncertainty and investment: system GMM estimates (dependent variable: real private investment / GDP ${ }^{2}$ )

\begin{tabular}{|c|c|c|c|}
\hline Equation & 1 & 2 & 3 \\
\hline Constant & $\begin{array}{l}-1.064^{* *} \\
(0.115)\end{array}$ & $\begin{array}{l}-1.031^{* *} \\
(0.117)\end{array}$ & $\begin{array}{l}-1.092^{* *} \\
(0.116)\end{array}$ \\
\hline Lagged private investment/ GDP ${ }^{2}$ & $\begin{array}{l}0.647^{* *} \\
(0.043)\end{array}$ & $\begin{array}{l}0.660^{* *} \\
(0.043)\end{array}$ & $\begin{array}{c}0.644^{* *} \\
(0.043)\end{array}$ \\
\hline Relative price of capital ${ }^{a}$ & $\begin{array}{l}-0.553^{* *} \\
(0.109)\end{array}$ & $\begin{array}{l}-0.546^{* *} \\
(0.111)\end{array}$ & $\begin{array}{l}-0.602^{* *} \\
(0.148)\end{array}$ \\
\hline Credit flow to priv. sector/GDP & $\begin{array}{l}3.229^{* *} \\
(1.004)\end{array}$ & $\begin{array}{l}3.196^{* *} \\
(1.004)\end{array}$ & $\begin{array}{l}3.364^{* *} \\
(0.960)\end{array}$ \\
\hline Real interest rate & $\begin{array}{l}-0.826^{* *} \\
(0.194)\end{array}$ & $\begin{array}{l}-0.831^{* *} \\
(0.193)\end{array}$ & $\begin{array}{l}-0.758^{* *} \\
(0.200)\end{array}$ \\
\hline Real exchange rate (RER) uncertainty ${ }^{b}$ & $\begin{array}{l}-1.831^{* *} \\
(0.703)\end{array}$ & $\begin{array}{l}-3.421^{* *} \\
(0.375)\end{array}$ & \\
\hline RER uncertainty squared & & $\begin{array}{c}4.848 \\
(3.406)\end{array}$ & \\
\hline High RER uncertainty $^{c}$ & & & $\begin{array}{l}-1.634^{* *} \\
(0.710)\end{array}$ \\
\hline Low RER uncertainty ${ }^{c}$ & & & $\begin{array}{c}3.544 \\
(8.153) \\
\end{array}$ \\
\hline Wald test of joint significance (p-value) & 0.000 & 0.000 & 0.000 \\
\hline Sargan test (p-value) & 0.457 & 0.319 & 0.433 \\
\hline 1st-order autocorrelation (p-value) & 0.000 & 0.000 & 0.000 \\
\hline 2nd-order autocorrelation (p-value) & 0.320 & 0.259 & 0.354 \\
\hline Number of observations (Countries) & $815(61)$ & $815(61)$ & $815(61)$ \\
\hline
\end{tabular}

Notes to table 1: Standard errors (in brackets) are heteroskedasticity consistent. One $\left({ }^{*}\right)$ and two $\left({ }^{* *}\right)$ stars denote statistical significance at the 10 and 5 percent level, respectively.
a. Expressed in logs.
b. Measured by the conditional variance from $\operatorname{GARCH}(1,1)$ estimates
c. Higher and lower than the average of the median country, respectively. 
Table 2

Factors shaping the investment impact of uncertainty: system GMM estimates (dependent variable: real private investment / GDP $^{2}$ )

\begin{tabular}{|c|c|c|c|c|c|c|}
\hline Equation & 1 & 2 & 3 & 4 & 5 & 6 \\
\hline Constant & $\begin{array}{c}-1.062^{* *} \\
(0.120)\end{array}$ & $\begin{array}{c}-1.071^{* *} \\
(0.120)\end{array}$ & $\begin{array}{c}-1.068^{* *} \\
(0.113)\end{array}$ & $\begin{array}{c}-1.104^{* *} \\
(0.125)\end{array}$ & $\begin{array}{c}-1.102^{* *} \\
(0.113)\end{array}$ & $\begin{array}{c}-1.124^{* *} \\
(0.137)\end{array}$ \\
\hline Lagged private investment/GDP ${ }^{a}$ & $\begin{array}{l}0.644^{* *} \\
(0.046)\end{array}$ & $\begin{array}{l}0.644^{* *} \\
(0.046)\end{array}$ & $\begin{array}{l}0.647^{* *} \\
(0.043)\end{array}$ & $\begin{array}{l}0.642^{* *} \\
(0.050)\end{array}$ & $\begin{array}{l}0.648^{* *} \\
(0.039)\end{array}$ & $\begin{array}{l}0.642^{* *} \\
(0.047)\end{array}$ \\
\hline Relative price of capital ${ }^{\mathrm{a}}$ & $\begin{array}{c}-0.563^{* *} \\
(0.122)\end{array}$ & $\begin{array}{c}-0.548^{* *} \\
(0.113)\end{array}$ & $\begin{array}{c}-0.568^{* *} \\
(0.121)\end{array}$ & $\begin{array}{c}-0.727^{* *} \\
(0.128)\end{array}$ & $\begin{array}{c}-0.674^{* *} \\
(0.122)\end{array}$ & $\begin{array}{c}-0.628^{* *} \\
(0.135)\end{array}$ \\
\hline Credit flow to priv. sector/GDP & $\begin{array}{l}3.053^{* *} \\
(0.967)\end{array}$ & $\begin{array}{l}3.223^{* *} \\
(1.002)\end{array}$ & $\begin{array}{l}3.207^{* *} \\
(1.003)\end{array}$ & $\begin{array}{l}3.033^{* *} \\
(0.948)\end{array}$ & $\begin{array}{l}3.398^{* *} \\
(0.990)\end{array}$ & $\begin{array}{l}3.732^{* *} \\
(1.000)\end{array}$ \\
\hline Real interest rate & $\begin{array}{c}-0.844^{* *} \\
(0.235)\end{array}$ & $\begin{array}{c}-0.852^{* *} \\
(0.238)\end{array}$ & $\begin{array}{c}-0.819^{* *} \\
(0.204)\end{array}$ & $\begin{array}{c}-0.951^{* *} \\
(0.237)\end{array}$ & $\begin{array}{c}-0.790^{* *} \\
(0.213)\end{array}$ & $\begin{array}{c}-0.898^{* *} \\
(0.232)\end{array}$ \\
\hline RER uncertainty $x$ high income ${ }^{c}$ & $\begin{array}{c}-1.219 \\
(2.438)\end{array}$ & & & $\begin{array}{c}-1.533 \\
(2.358)\end{array}$ & & \\
\hline RER uncertainty $x$ low income ${ }^{c}$ & $\begin{array}{c}-1.835^{* *} \\
(0.669)\end{array}$ & & & $\begin{array}{r}0.400 \\
(1.845)\end{array}$ & & \\
\hline RER uncertainty $x$ high $k / 1$ ratio $^{c}$ & & $\begin{array}{c}-2.176 \\
(2.280)\end{array}$ & & & & \\
\hline RER uncertainty $x$ low $k / 1$ ratio $^{c}$ & & $\begin{array}{c}-1.822^{* *} \\
(0.701)\end{array}$ & & & & \\
\hline RER uncertainty $x$ high fin depth ${ }^{c}$ & & & $\begin{array}{c}-0.822 \\
(1.093)\end{array}$ & & & \\
\hline RER uncertainty $x$ low fin depth ${ }^{c}$ & & & $\begin{array}{c}-3.369^{* *} \\
(0.957)\end{array}$ & $\begin{array}{l}-3.616^{*} \\
(1.889)\end{array}$ & & $\begin{array}{c}-7.294^{* *} \\
(1.990)\end{array}$ \\
\hline RER uncertainty $x$ high openness ${ }^{c}$ & & & & & $\begin{array}{c}-1.702 \\
(1.367)\end{array}$ & $\begin{array}{c}-1.658 \\
(1.568)\end{array}$ \\
\hline RER uncertainty $x$ low openness ${ }^{c}$ & & & & & $\begin{array}{c}-1.964^{* *} \\
(0.786) \\
\end{array}$ & $\begin{array}{l}5.064^{* *} \\
(2.059) \\
\end{array}$ \\
\hline Wald test of joint signif. ( $p$-value) & 0.000 & 0.000 & 0.000 & 0.000 & 0.000 & 0.000 \\
\hline Sargan test (p-value) & 0.319 & 0.398 & 0.427 & 0.336 & 0.418 & 0.511 \\
\hline 1st-order autocorrelation ( $p$-value) & 0.000 & 0.000 & 0.000 & 0.000 & 0.000 & 0.000 \\
\hline 2nd-order autocorrelation (p-value) & 0.271 & 0.325 & 0.232 & 0.192 & 0.310 & 0.201 \\
\hline Number of observations (Countries) & $815(61)$ & $815(61)$ & $815(61)$ & $815(61)$ & $815(61)$ & $815(61)$ \\
\hline
\end{tabular}

Notes to table 2: Standard errors (in brackets) are heteroskedasticity consistent. One $\left({ }^{*}\right)$ and two $\left({ }^{* *}\right)$ stars denote statistical significance at the 10 and 5 percent level, respectively.

a,b, c: see Table 1

For variable definitions, see text. 
Policy Research Working Paper Series

\section{Title}

WPS2806 Dirty Exports and Environmental Regulation: Do Standards Matter to Trade?

WPS 2807 The Role of Natural Resources in Fundamental Tax Reform in the Russian Federation

WPS2808 A Capital Accord for Emerging
Economies
WPS2809 On the Measurement and impact of
Fiscal Decentralization
HIV/AIDS Vaccine in Developing Countries WPS2812 Can Financial Markets be Tapped to
Help Poor People Cope with Weather
Risks?
WPS2811 The Epidemiological Impact of an

Author

Jahn S. Wilson

Tsunehiro Otsuki

Benoit Bosquet

Andrew Powell

Robert D. Ebel

Serdar Yilmaz

Luc Christiaensen

Lionel Demery

Stefano Paternostro

John Stover

Geoff P. Garnett

Steve Seitz

Steven Forsythe

Jerry Skees

Panos Varangis

Donald Larson

Paul Siegel

WPS2813 The Collective Model of the Household Kaushik Basu and an Unexpected Implication for Child Labor: Hypothesis and an

Empirical Test

WPS2814 Estimating the Endogenously Determined intrahousehold Balance Ranjan Ray of Power and lts Impact on Expenditure Pattern: Evidence from Nepal

WPS2815 Pricing Currency Risk: Facts and Puzzles from Currency Boards

WPS2816 Explaining the Migration of Stocks from Exchanges in Emerging Economies to International Centers

Sergio L. Schmukler Luis Servén

Stijn Claessens

Daniela Klingebiel

Sergio L. Schmukler

WPS2817 Does Sequencing Matter? Regulation Scott Wallsten and Privatization in Telecommunications Reforms

WPS28:8 Corporate Governance, Investor Protection, and Performance in Emerging Markets

Leora F. Klapper

Inessa Love

Shantayanan Devarajan Margaret J. Miller Eric V. Swanson
Prospects, and Costs
Date

Contact for paper

March 2002

P. Flewitt 32724

March 2002

D. Duff

39506

March 2002

E. Mekhova 85984

March 2002

M. Morris 37285

March 2002

N. Nouviale 34514

March 2002

H. Sladovich 37698

March 2002

P. Kokila 33716

March 2002

N. Jameson 30677

March 2002

N. Jamesci 30677

March 2002

E. Khine 37471

March 2002

E. Khine 37471

April 2002

P. Sintim-Aboray: 37644

April 2002

A. Yaptenco 31823

April 2002

S. Brickland 30944 
Policy Research Working Paper Stirs

\begin{tabular}{|c|c|c|c|c|}
\hline & Title & Author & Date & $\begin{array}{l}\text { Confact } \\
\text { for paper }\end{array}$ \\
\hline WPS2820 & $\begin{array}{l}\text { The Privatization of the Russian } \\
\text { Coal Industry: Policies and Processes } \\
\text { in the Transformation of a Major } \\
\text { Industry }\end{array}$ & $\begin{array}{l}\text { Igor Artemiev } \\
\text { Michael Haney }\end{array}$ & April 2002 & $\begin{array}{l}\text { V. Jcseph } \\
32: 55\end{array}$ \\
\hline WPS2821 & $\begin{array}{l}\text { income, Wealth, and Sociailzation } \\
\text { in Argentina: Provocative Responses } \\
\text { from Individuals }\end{array}$ & Daniel Lederman & April 2002 & $\begin{array}{l}\text { P. Soto } \\
37892\end{array}$ \\
\hline WPS2822 & $\begin{array}{l}\text { An Econometric Analysis of IBRD } \\
\text { Creditworthiness }\end{array}$ & David Mckenzie & Aprit 2002 & $\begin{array}{l}\text { C. Meridoza } \\
\text { jini ii }\end{array}$ \\
\hline
\end{tabular}

